\title{
Pengawasan terhadap Bank Tanah: Urgensi, Kewenangan, dan Mekanisme
}

\author{
Hasyim Sofyan Lahilote ${ }^{\star}$ Irwansyah ${ }^{\star \star}$, Rosdalina Bukido ${ }^{\star \star \star}$ \\ $\star \star \star \star \star$ Institut Agama Islam Negeri Manado \\ $\star \star$ Universitas Hasanuddin \\ *hasyim.lahilote@iain-manado.ac.id

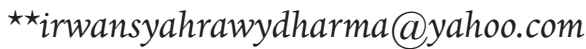

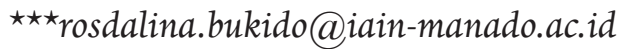

\begin{abstract}
The Omnibus Law for Job Creation establishes a special agency called the land bank agency that manages state land, including planning, acquisition, procurement, management, utilization, and distribution of land. This article revisits on how urgent this land bank is and how its supervisory powers and mechanisms are implemented. This article demonstrates that the formation of the land bank is actually related to problems in land acquisition, especially those intended for infrastructure development, which has triggered land liberalization and caused the increase of land price. Therefore, the land bank is urgent to ensure the availability of land for various development purposes in the future, budget efficiency, as well as to avoid conflicts in the land acquisition process and reduce the side effects of land liberalization. In order to encourage the land bank play its role and function as intended in its formation, good and efficient supervision is also needed. So far, it has been stated in the Omnibus Law for Job Creation that internal supervision is carried out by the supervisory board. Taking into account the relationship of the land bank and the supervisory board with other agencies or institutions that carry out the functions of land and bank as well as their supervision, like the one by the National Land Agency and the Financial Service Authority, it is necessary to have clarity on each role and function to avoid overlap.
\end{abstract}

Keywords: land banking; supervision; land acquisition. 


\section{Abstrak}

UU Cipta Kerja membentuk badan khusus yang mengelola tanah, yaitu badan bank tanah, yang berfungsi melaksanakan perencanaan, perolehan, pengadaan, pengelolaan, pemanfaatan, dan pendistribusian tanah. Dalam artikel ini dibahas apa sebetulnya urgensi bank tanah ini dan bagaimana pula kewenangan dan mekanisme pengawasannya. Artikel ini memperlihatkan pembentukan bank tanah sebetulnya terkait dengan permasalahan dalam pengadaan tanah terutama yang diperuntukkan bagi pembangunan infrastruktur, sehingga memicu terjadinya liberalisasi tanah dan mengakibatkan harga tanah melambung tinggi. Karena itu, bank tanah urgen dalam rangka menjamin ketersediaan tanah untuk berbagai keperluan pembangunan di masa yang akan datang, efisiensi anggaran, serta mengurangi konflik dalam proses pembebasan tanah dan dampak buruk liberalisasi tanah. Dalam rangka mendorong agar bank tanah berperan dan berfungsi sebagaimana dikehendaki dalam pembentukannya, maka diperlukan pengawasan yang baik dan efisien pula. Sejauh ini dalam UU Cipta disebutkan pengawasan dilakukan secara internal oleh dewan pengawas. Dengan mempertimbangkan adanya keterkaitan bank tanah dan dewan pengawas ini dengan badan atau lembaga lainnya yang menjalankan fungsi pertanahan dan bank serta pengawasannya juga, misal Badan Pertanahan Nasional dan Otoritas Jasa Keuangan, maka adanya kejelasan terhadap masing-masing peran dan fungsi sangatlah diperlukan, agar tidak malah terjadi tumpang tindih.

Kata kunci: bank tanah; pengawasan; pengadaan tanah.

\section{A. Pendahuluan}

Artikel ini membahas pengawasan operasionalisasi bank tanah yang dibentuk pemerintah pasca pemberlakuan Undang-undang Nomor 11 Tahun 2020 tentang Cipta Kerja (UU Cipta Kerja). Sebagai sistem dan kelembagaan yang baru, bank tanah dalam artikel ini akan ditelaah urgensi keberadaannya, serta kewenangan dan mekanisme pengawasannya.

Pembentukan bank tanah sendiri terkait dengan permasalahan dalam pengadaan tanah dewasa ini akibat pergeseran pandangan 
tentang tanah sebagai komoditas strategis. ${ }^{1} \mathrm{Hal}$ ini memicu terjadinya liberalisasi tanah yang mengakibatkan harga tanah melambung tinggi akibat permainan para spekulan tanah sehingga proyek-proyek yang direncanakan pemerintah dalam membangun infrastruktur terkendala masalah ganti rugi tanah. ${ }^{2}$ Terutama di perkotaan, tanah telah berubah menjadi suatu komoditas yang diperdagangkan dalam pasar yang sulit untuk dikendalikan terkait belum adanya strategi serta program yang efektif dalam membuat kebijakan pertanahan. ${ }^{3}$ Surono menginventarisasi permasalahan yang sering terjadi seputar pengadaan tanah bagi kepentingan umum, antara lain masalah data nominatif, nilai besaran ganti rugi, kesalahan administrasi dalam tahapan pengadaan tanah, adanya intimidasi oknum pelaksanan pengadaan tanah, dan indikasi markup obyek ganti rugi. ${ }^{4}$

1 Pandangan bahwa tanah merupakan komoditas yang strategis, mengemuka saat Kepala BPN/ Menteri Negara Agraria memberi sambutan pada Dies Natalis Universitas Muhammadiyah Yogyakarta, 2/4/1994. Dikatakan bahwa tanah sebagai komoditas strategis ditujukan untuk tersedianya tanah yang sesuai bagi setiap sektor pembangunan sehingga dapat mendorong investasi yang seluas-luasnya dan sebesa-besarnya dalam rangka menunjang tercapainya tingkat pertumbuhan ekonomi. Pandangan semacam ini muncul sebagai respons terhadap perebutan modal asing ke berbagai negara berkembang saat itu, sehingga Indonesia merasa perlu memberi fasilitas pengadaan tanah yang cepat dan murah (Endang Suhendar, "Editorial: Menjadikan Tanah sebagai Komoditas”, Jurnal Analisis Sosial, 3 [1996], hlm. 5-6). Pandangan tanah sebagai komoditas dikritik oleh Soediono M.P. Tjondrongeoro (“Tanah: Aset Utama Pembangunan”, Jurnal Analisis Sosial, 3 [1996]: 23-32), yang menyatakan bahwa tanah lebih tepat diidentifikasi sebagai aset. Komoditas oleh Soediono dipandang sebagai suatu barang atau ciptaan yang merupakan hasil produksi atau pemikiran yang dapat diperjualbelikan; sedangkan aset, sekalipun mirip, memiliki kelebihan yang tidak terdapat pada komoditas, yaitu ciri-ciri yang khas yang ditentukan oleh lokasi, komposisi, dan struktur partikel-partikel di dalamnya. Menyamakan aset dengan komoditas, berarti menghapus berbagai ikatan batin yang berakar dari tanah.

2 Hairani Mochtar, "Keberadaan Bank Tanah dalam Pengadaan Tanah untuk Pembangunan,” Jurnal Cakrawala Hukum, 18, 2 (2013), hlm. 127.

3 Herni Amir, Aminuddin Salle, dan Sri Susyanti Nur, "Kegiatan Bank Tanah sebagai Bentuk Penyediaan Tanah untuk Permukiman Rakyat,” Analisis, 3, 1 (2014), hlm. 34.

4 Agus Surono, "Perlindungan Hak Korban Pengadaan Tanah untuk Pembangunan Jalan Tol di Kabupaten Kendal," Jurnal Penelitian Hukum De Jure, 17, 4 (2017), hlm. 402. 
Salah satu cara untuk menyelesaikan permasalahan tersebut ialah dibentuknya bank tanah dalam rangka mengantisipasi adanya liberalisasi ekonomi yang mengakibatkan harga tanah melambung tinggi yang diakibatkan oleh permainan para spekulan. Harapannya, ketersediaan tanah dalam rangka pembangunan bisa diantisipasi lebih awal oleh pemerintah dengan pengadaan tanah bagi kepentingan umum yang dilakukan lebih awal. Karena itu, penerapan konsep bank tanah menjadi sangat urgen dilakukan di Indonesia mengingat instrumen tersebut dapat menyukseskan kebijakan pertanahan di tanah air serta dapat mendukung pengembangan wilayah secara efektif dan seefisien mungkin, dan dapat mengendalikan pengadaan, penguasaan serta pemanfaatan tanah secara wajar dan adil dalam menunjang pembangunan. ${ }^{5}$ Dengan diadakannya bank tanah, sedikitnya dapat menjawab berbagai permasalahan rumit yang terkait dalam penyediaan lahan untuk keperluan pembanguan serta menghemat anggaran pemerintah terutama dalam mengganti kerugian bagi masyarakat pemegang hak atas tanah.

Dengan disahkannya UU Cipta Kerja telah membuka cakrawala baru dalam pengadaan tanah di Indonesia. Dalam UU ini terdapat pengaturan tentang bank tanah yang diatur dalam Pasal 125 sampai Pasal 135. Pasal 125 ayat 4 mengatur fungsi bank tanah yang melaksanakan perencanaan, perolehan, pengadaan, pengelolaan, pemanfaatan, dan pendistribusian tanah. Akan tetapi terdapat kecurigaan berbagai kalangan dengan adanya undang-undang ini yang dikhawatirkan membuat adanya peningkatan hak menguasai negara atas tanah menjadi hak yang baru yaitu hak pengelolaan. Padahal, dalam UU Pokok-pokok Agraria tidak dikenal adanya hak pengelolaan oleh negara. Hak pengelolaan telah mengakibatkan kekacauan penguasaan tanah, karena merupakan wujud penyimpangan Hak Menguasai Negara (HMN). Putusan Mahkamah Konstitusi Nomor 001-021-022/PUU-1/2003 menegaskan bahwa HMN berarti kebijakan pengaturan, pengurusan, pengelolaan, dan

5 Fatimah Al Zahra, "Gagasan Pengaturan Bank Tanah untuk Mewujudkan Pengelolaan Aset Tanah Negara yang Berkeadilan,” Jurnal Ilmiah Administrasi Publik, 3, 2 (2017), hlm. 96. 
pengawasan yang mengacu pada Pasal 33 ayat 3 UUD 1945 dan bukan berarti negara memiliki tanah. Ketidaksesuaian ini akan mengonfirmasi kekhawatiran Maria Sumardjono, bahwa reformasi agraria dan sumber daya alam akhir-akhir ini telah menyebabkan terjadinya degradasi norma UU Pokok-pokok Agraria, yang semula diharapkan menjadi aturan yang bersifat umum (lex generalis) bagi aturan-aturan lain terutama sektor sumber daya alam justru menjadi aturan yang bersifat khusus pertanahan saja. ${ }^{6}$

Di samping itu timbul kecenderungan untuk menghidupkan kembali sistem domain verklaring, yaitu suatu sistem yang berasal dari zaman penjajahan Belanda yang menetapkan bahwa tanah menjadi milik negara jika tidak ada seseorang atau siapa pun yang bisa membuktikan kepemilikannya. Hal ini dikhawatirkan banyak tanah milik masyarakat adat yang akan menjadi milik negara karena sampai sekarang ini banyak tanah masyarakat adat yang tidak memiliki surat-surat tanah. Selain itu jika melihat tugas dan fungsi bank tanah di antaranya menyediakan dan mendistribusikan tanah, sejatinya hal tersebut telah dilaksanakan oleh Badan Layanan Umum (BLU) Lembaga Manjemen Aset Negara (LMAN) yang ada di bawah Kementerian Keuangan. Mulanya, LMAN bertanggung jawab atas pengelolaan aset milik negara, tetapi badan tersebut juga melakukan tugas perencanaan dana, menggunakan cadangan tanah dan membayar kompensasi dalam pengadaan tanah. ${ }^{7}$ Dari mandat baru tersebut membuat LMAN mempunyai fungsi tidak hanya sebagai treasurer atau financing provider, tapi juga spesial bank tanah untuk pengadaan tanah bagi pembangunan untuk kepentingan umum dan proyek strategis nasional sehingga terjadi tumpang tindih kewenangan dalam hal penyediaan dan pendistribusian tanah yang membuat keberadaan LMAN menjadi kurang efektif.

Berbagai permasalahan tersebut telah menambah kompleksitas

6 Anna Triningsih dan Zaka Firma Aditya, "Pembaharuan Penguasaan Hak atas Tanah dalam Perspektif Konstitusi," Jurnal Rechts Vinding: Media Pembinaan Hukum Nasional, 8, 3 (2019), hlm. 331.

7 Media Indonesia, "LMAN Ditugasi Mengatasi Pembebasan Tanah", $5 / 4 / 2017$. 
urgensi pengawasan operasioanalisasi bank tanah ke depan sehingga kekhawatiran-kekhawatiran yang timbul bisa diminimalisasi dengan sistem yang berjalan, serta penempatan sumber daya manusia yang mengelola bank tanah yang harus profesional dalam menjalankan operasionalisasi bank tanah. Dalam artikel ini, pembahasan tentang pengawasan operasionalisasi bank tanah diawali dengan uraian bank tanah dan pengelolaan tanah, dan dilanjutkan dengan bank tanah pasca UU Cipta Kerja. Bagian berikutnya mendiskusikan urgensi dan mekanisme pengawasan bank tanah. Artikel diakhiri dengan penyampaian kesimpulan.

\section{B. Bank Tanah dan Pengelolaan Tanah}

Definisi tentang bank tanah telah diungkapkan oleh berbagai penulis. Menurut Van Dijk, bank tanah adalah suatu mekanisme kegiatan pengambilalihan lahan yang sistematis dalam ukuran yang luas, yang akan dimanfaatkan pada waktu yang akan datang dalam pelaksanaan kebijakan pertanahan. ${ }^{8}$ Sedangkan menurut Maria Sumardjono, pengertian bank tanah sebagai setiap kegiatan pemerintah dalam rangka penyediaan tanah untuk dialokasikan pemanfaatannya di waktu yang akan datang. . Selanjutnya menurut Limbong, ${ }^{10}$ bank tanah adalah salah satu sarana manajemen sumber daya yang penting untuk meningkatkan produktivitas pemanfaatan tanah dengan metode yang diusung adalah kontrol pasar dan stabilisasi tanah pasar lokal.

UU Cipta Kerja, yang mengatur pembentukan bank tanah, atau secara lengkap disebut badan bank tanah, hanya menyebutnya sebagai

8 Hari Candra dan Afriva Khaidir, "Peluang dan Tantangan Bank Tanah Menuju Pemukiman Berwawasan Lingkungan di Indonesia,” JEBI: Jurnal Ekonomi dan Bisnis Islam, 5, 2 (2020), hlm. 5.

9 Era Alfansyuri, Syaiful Amri, dan Indra Farni, "Analisa Ketersediaan Tanah (Land Banking) untuk Perumahan dan Pemukiman dengan Sistem Informasi Geografis di Kabupaten Tanah Datar," Jurnal ilmiah Rekayasa Sipil, 17, 1 (2020), hlm. 98.

10 Bernhard Limbong, Bank Tanah (Jakarta: Margaretha Pustaka, 2013), hlm. 45. 
badan khusus yang mengelola tanah, ${ }^{11}$ yang fungsinya melaksanakan perencanaan, perolehan, pengadaan, pengelolaan, pemanfaatan, dan pendistribusian tanah. ${ }^{12}$ Peraturan pelaksana dari UU Cipta Kerja ini, yaitu Peraturan Pemerintah Nomor 64 Tahun 2021 tentang Badan Bank Tanah (PP Bank Tanah), yang mulai berlaku sejak diundangkan pada 29 April 2021, tidak pula mengatur lebih lanjut tentang definisi bank tanah ini, kecuali menambahkan bahwa bentuk bank tanah ini ialah badan hukum Indonesia, ${ }^{13}$ yang berkedudukan di ibukota negara ${ }^{14}$ dan mempunyai perwakilan di seluruh wilayah Indonesia. ${ }^{15}$

Bank tanah menjamin ketersediaan tanah untuk berbagai keperluan pembangunan di masa yang akan datang, efisiensi APBD / APBN, serta mengurangi konflik dalam proses pembebasan tanah dan mengurangi dampak buruk liberalisasi tanah. Sedangkan menurut Jack Damen, "land banking is the struktural acquisition and temporary management of land in rural areas by an impartial state agency, with the purpose to redistribute and/or lease out this land with a vieu to improve the agricultural structure and/or to re-locate the land for purposes with a general public interes." 16

Urgensibank tanah dalampembangunan adalahuntukmeminimalisasi pelaku-pelaku spekulan tanah disebabkan liberalisasi ekonomi yang memungkinkan tanah menjadi komoditas untuk mendapatkan keuntungan yang besar bagi para pemodal sehingga menyulitkan pemerintah dalam hal pengadaan dan pendistribusian tanah dalam pembangunan. ${ }^{17}$ Oleh karena itu dibutuhkan suatu lembaga yang

11 Pasal 125 ayat (2).

12 Pasal 125 ayat (4).

13 Pasal 2 ayat (1).

14 Pasal 2 ayat (5).

15 Pasal 2 ayat (6).

16 Jack Damen, "Land Banking in The Netherlands in the Context of Land Consolidation,” makalah International Workshop: Land Banking/Land Funds as an Instrument for Improved Land Management for CEEC and CIS, Tonder, Denmark, 17-20/3/2004, hlm. 1.

17 Pada mulanya, politik hukum pertanahan di Indonesia diarahkan untuk menjamin terwujudnya kemakmuran bagi seluruh rakyat. Selain ditunjukkan dalam bentuk prinsip-prinsip penguasaan dan pemanfaatan tanah untuk mendorong kemajuan bidang ekonomi, industri, dan bidang lain yang pelaksanaannya tergantung pada ketersediaan tanah, 
mengurus ketersediaan dan pengadaan tanah serta mendistribusikan pada masa yang akan datang untuk keperluan pembanguan atau untuk urusan-urusan lain seperti sosial, pemerintahan, pemukiman warga negara, maupun urusan lain yang ditetapkan oleh undangundang.

Penggunaan suatu lembaga yang diatur negara untuk mengelola pengadaan dan pendistribusian tanah dalam rangka konsolidasi pada waktu yang akan datang guna tersedianya alokasi tanah dalam rangka pembangunan, merupakan hal yang telah lama dilakukan di negaranegara Eropa. Menurut Jack Damen, Belanda telah menerapkan sistem ini sejak 1841 dengan membentuk suatu lembaga di bawah Kementerian Keuangan yang mengurus layanan bidang pertanahan yang mengelola perkembangan kebijakan pemerintah di bidang pertanahan, pengelolaan tanah milik negara, fasilitasi penggunaan tanah negara, serta penjualan tanah negara. ${ }^{18}$

Secara historis praktik pengadaan tanah di Indonesia dilakukan semenjak Indonesia merdeka dan secara yuridis mendapatkan payung hukumnya sejak dikeluarkannya UU Pokok-pokok Agraria. Pasal 6 UU ini menggarisbawahi bahwa setiap hak atas tanah mempunyai fungsi sosial, hal ini menandakan bahwa setiap pemegang hak atas tanah wajib melepaskan hak tersebut bilamana kepentingan umum menghendaki. Pengaturan tentang pengadaan tanah bagi pembangunan diatur dalam UU Pengadaan Tanah. Dalam UU ini, pengadaan tanah dinyatakan sebagai kegiatan menyediakan tanah dengan cara memberi ganti kerugian yang layak dan adil kepada

hal itu juga terlihat dari materi muatan UU Pokok-pokok Agraria yang memberi perhatian khusus terhadap kelompok masyarakat lemah dan termarjinalkan. Namun arah politik hukum ini berubah seiring ideologi pembangunan yang dikembangkan pada masa Orde Baru, sehingga mengarah pada liberalisasi dan swastanisasi penguasaan dan pemanfaatan tanah. Pasca reformasi sebetulnya telah ada upaya untuk menghidupkan kebijakan yang mengembalikan keseimbangan seperti terkandung dalam UU Pokok-pokok Agraria, namun tidak cukup mendapatkan dukungan dari instansi sektoral termasuk aparat penegak hukum. Nurhasan Ismail, "Arah Politik Hukum Pertanahan dan Perlindungan Kepemilikan Tanah Masyarakat”, Jurnal Rechtsvinding, 1, 1 (2012), hlm. 50.

18 Damen, "Land Banking in The Netherlands," hlm. 6. 
pihak yang berhak, dan diselenggarakan melalui beberapa tahapan yang dimulai dengan perencanaan, persediaan, pelaksanaan dan penyerahan hasil. Dalam rangka pengadaan dan pengorganisasian tanah untuk pembangunan, Menteri Keuangan telah membentuk suatu lembaga yang berada di bawah Kementerian Keuangan berupa LMAN yang mempunyai tugas antara lain perencanaan kebutuhan dan pengembangan lahan/tanah, pengelolaan dana investasi pemerintah termasuk pendanaan pengadaann tanah untuk proyek strategis nasional sebagaimana diatur dalam peraturan perundangundangan. ${ }^{19}$

Secara yuridis pengaturan bank tanah di Indonesia dimulai dengan dikeluarkannya UU Cipta Kerja yang disahkan pada 5 Oktober 2020. Peraturan tentang bank tanah dalam UU ini termuat dalam 10 pasal, yang diawali dengan Pasal 125 yang memuat penjelasan beserta fungsi yang akan dijalankan oleh bank tanah, kemudian Pasal 26 yang menjelaskan sifat bank tanah yang menjamin ketersediaan tanah untuk masyarakat, dilanjutkan Pasal 27 yang menggarisbawahi pelaksanaan tugas bank tanah yang bersifat transparan, akuntabel dan berorientasi non profit, serta Pasal 128-129 yang memuat ketentuan kekayaan bank tanah, pengelolaan hak atas tanah dan organisasi bank tanah, sedangkan Pasal 130-135 memuat penjelasan dari masingmasing organisasi pada bank tanah. Dengan diberlakukannya pasalpasal tentang bank tanah tersebut diharapkan menjadi efektif dalam pengaturan tanah di tanah air.

Dari aspek hukum, keefektifan penerapan bank tanah akan ditentukan pula oleh regulasi yang mengaturnya, misalnya bentuk kelembagaan, tujuan, serta berbagai mekanisme penyelenggaraannya. ${ }^{20}$ Secara umum pelaksanaan aturan tentang bank tanah masih memerlukan peraturan pemerintah disertai aturan pelaksana lainnya di tingkat menteri untuk mempertegas proses pelaksanaannya sesuai

19 Pasal 2 huruf h Peraturan Menteri Keuangan Nomor 54/PMK.01/2017 tentang Organisasi dan Tata Kerja Organisasi LMAN.

20 Fatimah Al Zahra, "Konstruksi Hukum Pengaturan Bank Tanah untuk Mewujudkan Pengelolaan Aset Tanah Negara Berkeadilan,” Arena Hukum, 10, 3 (2018), hlm. 374. 
amanat UU Cipta Kerja sehingga pelaksanaannya sesuai dengan citacita filosofis serta yuridis yang terkandung di dalamnya. Selain dalam UU Cipta Kerja, aturan pelaksana terkait bank tanah saat ini telah diatur dalam PP Bank Tanah.

Akibat hukum diadakannya bank tanah melalui pengesahan UU Cipta Kerja adalah terbentuknya badan baru yang khusus mengelola tanah. Hal ini telah menambah kewenangan pemerintah di bidang pertanahan yang pada awalnya merupakan regulator di bidang pertanahan melalui Badan Pertanahan Nasional yang dibentuk berdasarkan Peraturan Presiden Nomor 20 tahun 2015, ditambah dengan ketentuan Pasal 125 ayat 2 UU Cipta Kerja tentang pendirian bank tanah yang berfungsi sebagai pengelola tanah.

Dari sisi kelembagaan, pemerintah sebagai pelaksana pengadaan tanah melalui bank tanah harus mampu menjaga keseimbangan terhadap kebutuhan atas tanah yang semakin meningkat dengan sumber daya tanah yang bersifat tetap. ${ }^{21}$ Selain bank tanah ini, secara kelembagaan saat ini juga telah ada lembaga yang mengurusi pertanahan yaitu, Badan Pertanahan Nasional (BPN). Dengan adanya dua lembaga yang mengurusi hal pokok yang sama, yaitu pertanahan, dikhawatirkan terjadi tumpang tindih kewenangan terutama untuk masalah pengadaan tanah. Di satu sisi BPN dalam ketentuan Pasal 3 huruf e Peraturan Presiden Nomor 20 Tahun 2015 menyelenggarakan fungsi perumusan dan pelaksanaan kebijakan di bidang pengadaan tanah, pada sisi yang lain melalui ketentuan Pasal 125 ayat 4 UU Cipta Kerja, bank tanah berfungsi melaksanakan perencanaan, perolehan, pengadaan, pengelolaan, pemanfaatan, dan pendistribusian tanah. Di sisi lain, dengan adanya bank tanah telah membuka kewenangan yang baru berupa hak pengelolaan oleh negara yang diberikan oleh peraturan setingkat UU berdasarkan ketentuan Pasal 129 ayat 1 UU Cipta Kerja, yang sebelumnya tidak diatur dalam UU Pokok-pokok Agraria. Sebaliknya, UU ini hanya mengatur tentang HMN berdasarkan ketentuan Pasal 2. Karena itu,

21 Wahyu Benny Mukti Setiyawan dan Nabila Chyntia Dahani, "Model Bank Tanah Pertanian untuk Mewujudkan Indonesia Berdaulat Pangan," Qistie: Jurnal Ilmu Hukum, 13, 1 (2020), hlm. 82. 
melalui dua instrumen hukum tersebut, jika tidak dipisah atau dibagi secara seimbang, dikhawatirkan akan terjadi overlapping terhadap berbagai kebijakan di bidang pengadaan tanah.

Menurut Urip Santoso, terdapat perbedaan pendapat mengenai kedudukan hak pengelolaan dalam hukum tanah nasional di kalangan pakar hukum tanah. Sebagian ahli hukum ada yang berpendapat bahwa hak pengelolaan merupakan hak menguasai negara atas tanah dan di pihak lain, ada pula yang berpendapat bahwa hak pengelolaan merupakan hak atas tanah. Perbedaan pendapat ini disebabkan oleh eksistensi hak pengelolaan yang tidak diatur dalam UU Pokokpokok Agraria, melainkan diatur dalam Peraturan Menteri Agraria. ${ }^{22}$ Ketentuan yang mengatur tentang hak pengelolaan lahan oleh negara hanya diatur dalam Peraturan Menteri Agraria Nomor 9 Tahun 1965 tentang Pelaksanaan Konversi Hak Penguasaan atas Tanah Negara dan dilanjutkan dengan ketentuan Pasal 2 ayat 3 huruf f Undangundang Nomor 21 Tahun 1997 tentang Bea Perolehan Hak atas Tanah. Sedangkan pengaturan lainnya tentang hak pengelolaan tanah oleh negara juga diatur dalam Pasal 1 angka 3 Peraturan Menteri Negara Agraria/Kepala BPN Nomor 9 Tahun 1999 tentang Tata Cara Pemberian dan Pembatalan Hak atas Tanah dan Pengelolaan, di mana dijelaskan bahwa hak pengelolaan adalah hak menguasai dari negara yang kewenangan pelaksanaannya sebagian dilimpahkan kepada pemegangnya. Dengan adanya UU Cipta Kerja yang secara eksplisit menyatakan kewenangan hak pengelolaan tanah oleh negara melalui bank tanah telah membuat suatu norma hukum yang baru tentang hak pengelolaan lahan oleh negara yang menegaskan kembali eksistensi negara bukan hanya dalam hal hak menguasai negara atas tanah, akan tetapi juga menyangkut pengelolaan tanah di dalam negeri.

\section{Pengawasan Bank Tanah}

Pembentukan bank tanah melalui UU Cipta Kerja telah membuat

22 Urip Santoso, "Eksistensi Hak Pengelolaan dalam Hukum Tanah Nasional," Mimbar Hukum, 24, 2 (2012), hlm. 278. 
instrumen pengelolaan tanah menjadi domain negara, sehingga perlu pengawasan untuk memantau pelaksanaan atau operasionalisasinya. Bagian ini menelaah bagaimana kewenangan dan mekanisme pengawasan terkait pelaksanaan atau operasionalisasi bank tanah.

Secara bahasa, pengawasan adalah "penilikan dan penjagaan", ${ }^{23}$ yang berarti suatu penilikan atau penjagaan terhadap suatu hal, dalam hal ini operasionalisasi bank tanah itu sendiri. Dalam manajemen organisasi, pengawasan (controlling) adalah suatu kegiatan untuk mencocokkan apakah kegiatan operasional (actuating) di lapangan telah sesuai dengan rencana (planning) yang telah ditetapkan dalam mencapai tujuan (goal) dari organisasi. Dengan begitu, yang menjadi obyek dari kegiatan pengawasan adalah mengenai kesalahan, penyimpangan, cacat dan hal-hal lain yang bersifat negatif. ${ }^{24}$

Menurut Effendi, pengawasan adalah segala tindakan atau aktivitas untuk menjamin agar pelaksanaan suatu aktivitas tidak menyimpang dari rencana yang telah ditetapkan. Tujuan utamanya bukan untuk mencari kesalahan, melainkan mengarahkan pelaksanaan aktivitas agar rencana yang telah ditetapkan dapat terlaksana secara optimal. ${ }^{25}$ Dalam hukum administrasi, meningkatnya kualitas dan kuantitas tugas-tugas yang harus diselenggarakan pemerintah menimbulkan konsekuensi pada perlunya sistem pengawasan yang lebih intensif dan efektif untuk mengoreksi terjadinya praktik-praktik maladministrasi. ${ }^{26}$

Pengawasan dalam hukum administrasi, sebagaimana dijelaskan Paulus E Lotulung, dibedakan ke dalam tiga hal. Dari aspek kedudukan organ yang mengawasi, maka pengawasan dibedakan antara

23 https://kbbi.kemdikbud.go.id/entri/pengawasan.

24 Sentot Harman Glendoh, "Fungsi Pengawasan dalam Penyelenggaraan Manajemen Korporasi”, Jurnal Manajemen \& Kewirausahaan, 2, 1 (2000), hlm. 46.

25 Askam Tuasikal, "Pengaruh Pengawasan, Pemahaman Sistem Akuntansi Keuangan dan Pengelolaan Keuangan terhadap Kinerja Unit Satuan Kerja Pemerintah Daerah (Studi pada Kabupaten dan Kota di Provinsi Maluku)," Jurnal Keuangan dan Perbankan, 10, 1 (2017), hlm. 3.

26 Soehartono, "Eksistensi Asas-asas Umum Pemerintahan yang Baik sebagai Dasar Pengujian Keabsahan Keputusan Tata Usaha Negara di Peradilan Tata Usaha Negara", Yustisia, 1, 2 (2012), hlm. 184. 
pengawas internal dan eksternal. Pengawasan internal dilakukan secara organisatoris atau struktural di wilayah internalnya; sedangkan pengawasan eksternal dilakukan oleh organisasi atau struktur yang di luar yang memang diberi tugas dan fungsi mengawasi. Dari aspek tempo atau waktu, pengawasan dibedakan antara yang apriori dan aposteriori. Kontrolapriori dilakukan sejak dini sebelum diterbitkannya keputusan atau ketetapan pemerintah, sedangkan kontrol aposteriori dilakukan setelah ada keputusan atau ketetapan tersebut. Dari objek pengawasan, dibedakan antara segi hukum (rechmatigheid) dan kemanfaatan (doelmatigheid). Kontrol dari segi hukum maksudnya adalah pertimbangan aspek hukum atau legalitasnya, sedangkan kontrol dari segi kemanfaatan adalah untuk menguji apakan suatu tindakan dibenarkan atau tidak. ${ }^{27}$

Dalam kaitannya dengan pengawasan bank tanah, istilah yang digunakan sendiri bisa memunculkan permasalahan, yaitu peristilahan bank dalam bank tanah. Menurut Dendawijaya, sebagaimana dikutip Rahmadhani dan Mawardi, bank adalah badan usaha yang menghimpun dana dari masyarakat dalam bentuk simpanan dan menyalurkannya kepada masyarakat dalam bentuk kredit dan atau bentuk lainnya dalam rangka meningkatkan taraf hidup orang banyak. ${ }^{28}$ Dengan definisi ini sangat jelas bahwa yang dikelola oleh bank adalah dana masyarakat. Sementara itu, dalam bank tanah, yang dikelola adalah tanah, baik yang dikuasasi oleh negara maupun yang dimiliki oleh masyarakat. Dengan perbedaan dalam hal obyek pengelolaan tersebut, timbul pertanyaan apakah istilah bank dalam domain bank tanah bisa dipersamakan dengan bank dalam istilah sehari-hari. Hal ini mengindikasikan apakah sistem yang dianut oleh bank tanah ini akan sesuai dengan sistem perbankan yang dikenal dan

27 Nehru Asyikin, "Pengawasan Publik terhadap Pejabat Publik yang Melakukan Tindakan Korupsi: Perspektif Hukum Administrasi”, Wawasan Yuridika, 4, 1 (2020), hlm. 94.

28 Lintang Rahmadhani, "Analisis Pengaruh CAR, Pertumbuhan DPK, Pertumbuhan Simpanan dari Bank Lain dan Suku Bunga SBI terhadap Pertumbuhan Kredit (Studi Kasus pada Bank Umum Konvensional yang Terdaftar di BEI Periode 2006-2010)” (Disertasi, Universitas Diponegoro, Semarang, 2011), hlm. 2. 
telah ada peraturan perundang-undangan yang mengaturnya, atau istilah ini hanyalah merupakan kesamaan nama dalam peristilahan, mengingat kesamaan tugas pokok dan fungsi dari bank tanah yang hampir sama dengan bank pada umumnya.

Secara garis besar konsep bank tanah dengan bank konvensional mempunyai persamaan dan perbedaan. Limbongsebagaimana dikutip oleh Ganindha menyatakan bahwa terdapat persamaan dan perbedaan baik dari segi fungsi, pelaksanaan maupun operasionalisasi. Dari segi fungsi, kedua lembaga dapat mempunyai fungsi untuk menyimpan aset, membantu stabilisasi pasar sekunder, serta memegang cabang modal. Sedangkan perbedaannya adalah, bank tanah menyimpan sekaligus mengelola tanah, sementara bank konvensional menyimpan dan mengelola uang dan benda berharga dan surat berharga lainnya. Dari segi pelaksanannya kedua lembaga dapat dilaksanakan oleh pemerintah maupun swasta, sedangkan perbedaannya bank tanah fokus pada stabilisasi lingkungan dan masyarakat serta penggunaan tanah sedangkan bank konvensional fokus pada pasar nasional dan pasar internasional. Dari segi operasionalisasinya, kedua lembaga beroperasi dalam kerangka regulasi, sedangkan perbedaannya bank tanah berorientasi nirlaba dan bank konvensional berdasarkan profit oriented. ${ }^{29}$

Jika melihat tugas pokok dan fungsi bank tanah yang mempunyai kesamaan dengan bank konvensional pada umumnya, maka operasional bank tanah pada sebagian ketentuan bisa menundukkan diri pada aturan-aturan tentang perbankan yang telah ada. Misal, Undangundang Nomor 10 Tahun 1998 tentang Perubahan atas Undangundang Nomor 7 Tahun 1992 tentang Perbankan, Undang-undang Nomor 3 Tahun 2004 tentang Perubahan atas Undang-undang Nomor 23 Tahun 1999 tentang Bank Indonesia, serta Undang-undang Nomor 21 Tahun 2011 tentang Otoritas Jasa Keuangan, beserta aturan-aturan pelaksana lainnya. Hal ini dikarenakan sampai saat ini pemerintah belum menerbitkan peraturan pemerintah tentang

29 Ranitya Ganindha, "Urgensi Pembentukan Kelembagaan Tanah sebagai Solusi Pengadaan Tanah bagi Pembangunan untuk Kepentingan Umum yang Nirkonflik”, Arena Hukum, 9, 3 (2017), hlm. 448. 
bank tanah yang merupakan aturan pelaksana sebagai aturan yang mengatur operasionalisasi bank tanah ke depan.

Bank tanah sendiri merupakan suatu kebijakan agraria di mana lembaga diberi kewenangan oleh negara dalam mengakuisisi sebuah tanah yang tidak dipakai ataupun tanah yang bermasalah baik tanah yang belum dan perlu dikembangkan maupun tanah yang dianggap memiliki potensi dalam jangka pendek maupun jangka panjang. Selain itu bank tanah bertugas dalam pengelolaan dan pengaturan tanah selama tanah itu masih belum digunakan. Selanjutnya bank tanah dapat melakukan redistribusi atas tanah tersebut demi kepentingan umum berdasarkan gagasan yang dibuat oleh pemerintah, khususnya dalam program jangka panjang. ${ }^{30}$

Pada sisi lain, sebagai lembaga yang mengurus pengadaan dan distribusi tanah, bank tanah dalam operasionalnya tunduk pada aturan UU Pokok-pokok Agraria dan UU Pengadaan Tanah. UU Cipta Kerja hanya menyebutkan pembentukan bank tanah secara kelembagaan, sedangkan masalah-masalah yang bersifat tanah secara khusus telah diatur sepenuhnya oleh kedua peraturan yang telah disebutkan di atas.

Jika mencermati UU Cipta Kerja, mekanisme pengawasan secara internal telah diantisipasi dengan membentuk dewan pengawas melalui ketentuan Pasal 130 huruf b, yang kemudian diatur lebih lanjut dalam PP Bank Tanah. Pada PP disebutkan, dewan pengawas adalah "organ bank tanah yang memiliki tugas untuk mengawasi seluruh kegiatan bank tanah serta menyampaikan rekomendasi atas pelaksanaan kebijakan penyelenggaran bank tanah". ${ }^{31}$ Ketentuan lainnya tentang dewan pengawas hanya seputar komposisi dan penetapannya. Secara komposisi, dewan pengawas berjumlah paling banyak tujuh orang yang terdiri dari empat dari unsur profesional dan tiga dipilih oleh pemerintah pusat. ${ }^{32}$

Melihat hal ini dapat disadari bahwa pengurus bank tanah ini sangat berkesinambungan satu sama lain, di mana badan pelaksana

30 Limbong, Bank Tanah, hlm. 70.

31 Pasal 1 angka 6; Pasal 31 ayat (4).

32 Pasal 132 ayat (1) UU Cipta Kerja; Pasal 33 ayat (2) dan (3) PP Bank Tanah. 
berwenang untuk mengelola tanah sebagai hak guna usaha, hak guna bangunan dan hak pakai, sedangkan dewan pengawas berwenang untuk mengawasi aktivitas yang dilakukan oleh badan pelaksana. Kewenangan dewan pengawas ini dapat mengurangi kekhawatiran jika akan terjadinya pelaksanaanyang merugikan khalayak umum dan negara namun menguntungkan diri maupun kelompok.

Berkaitan dengan peran dewan pengawas, bisa saja diambil analogi terhadap badan-badan lain sejenis yang mempunyai mekanisme pengawasan internal. Pada umumnya dewan pengawas badanbadan tersebut bertugas melakukan pengawasan atas kebijakan pengelolaan yang dilakukan oleh badan pelaksana, melakukan pengawasan atas pelaksanaan pengelolaan yang dilakukan oleh badan pelaksana, memberikan saran/nasehat serta pertimbangan kepada badan pelaksana dalam pengelolaan, serta meyampaikan laporan pengawasan. Dengan adanya prosedur pengawasan tersebut maka pengawasan yang sifatnya preventif diharapkan mampu meminimalisasi penyalahgunaan kewenangan oleh badan pelaksana yang mengelola bank tanah ke depan.

Selanjutnya, dalam pengawasan eksternal masih timbul tanda tanya dalamhalapakahpengawasan eksternalakandilakukanolehBPN yang merupakan regulator bidang pertanahan yang selama ini telah eksis dalam hal pertanahan, ataukah akan dilakukan oleh OJK yang selama ini telah melakukan pengawasan terhadap pengelolaan jasa keuangan termasuk perbankan. Terdapat perbedaan antara institusi BPN dengan badan bank tanah yang akan dibentuk berdasarkan UU Cipta Kerja, walaupun keduanya sama-sama merupakan badan yang mengurusi pertanahan secara umum. Perbedaan tersebut terletak pada fungsi masing-masing badan yang diberikan tugas berbeda. BPN di satu sisi dalam masalah pertanahan berfungsi dan bertindak sebagai regulator, sedangkan badan bank tanah berfungsi dan bertindak sebagai pengelola lahan (land manager). Pada penerapan di beberapa negara, badan yang mengurusi pertanahan seperti BPN mempunyai dua fungsi, yaitu sebagai regulator dan sebagai pengelola lahan (land manager). Akan tetapi di Indonesia kebijakan pengurusan masalahmasalah pertanahan diberikan kepada dua badan yang berbeda, yaitu 
BPN sebagai regulator dan bank tanah sebagai pengelola lahan (land manager). Hal ini berbeda jika dikaitkan dengan pengelolaan hutan di Indonesia, di mana Kementerian Lingkungan Hidup dan Kehutanan, berfungsi sebagai regulator sekaligus sebagai pengelola kehutanan di Indonesia. Bank tanah mempunyai tugas sebagai perantara (intermediary) antara pemilik lahan dan yang membutuhkan lahan. Praktik ini layaknya berlaku di kalangan perbankan pada umumnya yang menjadi perantara dari pemilik dana dan yang membutuhkan dana.

Adanya lembaga baru sebagai pengelola tanah negara telah memunculkan kekhawatiran digunakannya instrumen negara sebagai alat untuk memperluas praktik-praktik liberalisasi tanah secara luas dengan menggunakan hak pengelolaan lahan yang dimiliki oleh negara. Pamungkas dan Winarso mengaskan kepemilikan lahan publik juga dikritisi oleh beberapa pihak yang dijelaskan pula dalam tiga argumen, yaitu inefisiensi birokrasi, monopoli publik yang mengancam hak privat, serta dinamika nilai lahan. ${ }^{33}$ Selama ini praktik-praktik liberalisasi tanah telah digunakan oleh para spekulan tanah dengan menggunakan rencana pembangunan yang dimiliki oleh Kementerian Agraria dan Tata Ruang BPN/RI untuk dilakukan pembelian awal terhadap lokasi-lokasi tanah yang akan digunakan pemerintah untuk kepentingan pembangunan dengan harga yang relatif rendah, dan kemudian menjualnya kembali kepada pemerintah dengan harga yang sangat tinggi yang mengakibatkan pemerintah mengalami kesulitan dalam hal pembebasan lahan dalam pembangunan terutama dalam hal ganti kerugian.

Dalam Pasal 128 UU Cipta Kerja dinyatakan bahwa sumber kekayaan bank tanah dapat berasal dari APBN, pendapatan sendiri, penyertaan modal negara, sumber lain yang sah sesuai ketentuan peraturan perundang-undangan. Adanya ketentuan sumber pendapatan lain dalam kekayaan bank tanah dikhawatirkan bisa menjadi celah pintu masuk baru bagi para investor dan pemilik dana/ modal pelaku liberalisasi tanah dalam hal ini spekulan tanah untuk

33 Azhari Pamungkas dan Haryo Winarso, "Bentuk Kelembagaan dan Pola Pembiayaan Land Banking Publik di Indonesia,” Tataloka, 20, 1 (2018), hlm. 37. 
menyumbangkan dananya untuk kepentingan operasionalisasi bank tanah sehingga bisa mempengaruhi kebijakan-kebijakan yang diambil oleh badan pelaksana dalam pengelolaan tanah.

Dengan demikian, bank tanah ini bisa menjadi sebuah bentuk alternatif tentang cara menyediakan tanah tanpa konflik, apalagi untuk pencegahan berbagai macam masalah dalam penyediaan tanah dan tercapainya pembangunan untuk kepentingan umum. Namun demikian, agar bank tanah ini terselenggara sebagaimana peran dan fungsi yang dikehendaki, maka tentu saja pengawasannya harus pula dilakukan dengan baik dan efisien. Sekalipun pengawasan ini terutama pengawasan internal secara kewenangan dan mekanisme telah diatur dalam UU Cipta Kerja dan PP Bank Tanah, yaitu melalui suatu organ yang disebut dewan pengawas, keberadaannya yang secara yuridis masih sangat baru dan adanya keterkaitan dengan kelembagaan lainnya yang mempunyai fungsi yang dalam beberapa hal sama, memerlukan kejelasan lebih lanjut agar tidak malah tumpang tindih.

\section{Kesimpulan}

Pengawasan terhadap operasionalisasi bank tanah mutlak diperlukan mengingat posisi bank tanah sebagai pengelola pertanahan yang secara prinsip menyangkut hajat hidup orang banyak terutama bidang pertanahan. Melalui pengawasan baik internal maupun eksternal diharapkan bisa meminimalisasi perilaku liberalisasi pertanahan terutama masalah perizinan dan penggunaan tanah dalam rangka pembangunan yang diharapkan dapat meningkatkan efisiensi dan pemanfaatan yang strategis sesuai dengan peruntukannya. Mekanisme pengawasan bank tanah dalam UU Cipta Kerja akan memberikan langkah preventif dalam meminimalisasi wewenang atas bank tanah yang akan disalahgunakan di kemudian hari. Kelembagaan dan kewenangan pengawasan bank tanah melalui organ dewan pengawas, sebagaimana dimaksud dalam UU Cipta Kerja, diharapkan dapat mendorong kinerja dan operasionalisasi bank tanah sesuai dengan peran dan fungsinya. Hanya saja, adanya 
keterkaitan bank tanah dan dewan pengawas ini dengan organ maupun pengawasan dalam bidang pertanahan dan bank yang juga ada pada lembaga atau badan lainnya, terutama yang sejauh ini telah berlangsung yaitu BPN dan OJK, memerlukan pula kejelasan lebih lanjut terkait kewenangan dan mekanismenya.

\section{Daftar Pustaka}

Alfansyuri, Era, Syaiful Amri, dan Indra Farni. "Analisa Ketersediaan Tanah (Land Banking) untuk Perumahan dan Pemukiman dengan Sistem Informasi Geografis di Kabupaten Tanah Datar.” Jurnal Ilmiah Rekayasa Sipil, 17, 1 (2020): 96-105. DOI: 10.30630/ jirs.17.1.242.

Amir, Herni, Aminuddin Salle, dan Sri Susyanti Nur. "Kegiatan Bank Tanah sebagai Bentuk Penyediaan Tanah untuk Permukiman Rakyat." Analisis, 3, 1 (2014): 29-36.

Asyikin, Nehru. "Pengawasan Publik terhadap Pejabat Publik yang Melakukan Tindakan Korupsi: Perspektif Hukum Administrasi”. Wawasan Yuridika, 4, 1 (2020): 80-102. DOI: 10.25072/jwy. v4i1.316.

Candra, Hari dan Afriva Khaidir. "Peluang dan Tantangan Bank Tanah Menuju Pemukiman Berwawasan Lingkungan di Indonesia." JEBI: Jurnal Ekonomi dan Bisnis Islam, 5, 2 (2020): 1-20. DOI: 10.15548/jebi.v5i2.274.

Damen, Jack. "Land Banking in The Netherlands in the Context of Land Consolidation." Makalah International Workshop: Land Banking/Land Funds as an Instrument for Improved Land Management for CEEC and CIS, Tonder, Denmark, 1720/3/2004.

Ganindha, Ranitya. "Urgensi Pembentukan Kelembagaan Tanah sebagai Solusi Pengadaan Tanah bagi Pembangunan untuk Kepentingan Umum yang Nirkonflik.” Arena Hukum, 9, 3 (2017): 442-62. DOI: 10.21776/ub.arenahukum.2016.00903.8.

Glendoh, Sentot Harman. "Fungsi Pengawasan dalam Penyelenggaraan Manajemen Korporasi”. Jurnal Manajemen \& Kewi- 
rausahaan, 2, 1 (2000): 43-56.

Ismail, Nurhasan. "Arah Politik Hukum Pertanahan dan Perlindungan Kepemilikan Tanah Masyarakat". Jurnal Rechtsvinding, 1, 1 (2012): 33-52.

Limbong, Bernhard. Bank Tanah. Jakarta: Margaretha Pustaka, 2013. Media Indonesia. "LMAN Ditugasi Mengatasi Pembebasan Tanah". $5 / 4 / 2017$.

Mochtar, Hairani. "Keberadaan Bank Tanah dalam Pengadaan Tanah untuk Pembangunan.” Jurnal Cakrawala Hukum, 18, 2 (2013): 127-35.

Pamungkas, Azhari, dan Haryo Winarso. "Bentuk Kelembagaan dan Pola Pembiayaan Land Banking Publik di Indonesia.” Tataloka, 20, 1 (2018): 35-49. DOI: 10.14710/tataloka.20.1.35-49.

Rahmadhani, Lintang. "Analisis Pengaruh CAR, Pertumbuhan DPK, Pertumbuhan Simpanan dari Bank Lain dan Suku Bunga SBI terhadap Pertumbuhan Kredit (Studi Kasus pada Bank Umum Konvensional yang Terdaftar di BEI Periode 2006-2010)." Disertasi, Universitas Diponegoro, Semarang, 2011.

Santoso, Urip. "Eksistensi Hak Pengelolaan dalam Hukum Tanah Nasional." Mimbar Hukum, 24, 2 (2012): 275-88. DOI: 10.22146/ jmh.16130.

Setiyawan, Wahyu Benny Mukti, dan Nabila Chyntia Dahani. "Model

Bank Tanah Pertanian untuk Mewujudkan Indonesia Berdaulat Pangan.” Qistie: Jurnal Ilmu Hukum, 13, 1 (2020): 78-95. DOI: 10.31942/jqi.v13i1.3427.

Soehartono. "Eksistensi Asas-asas Umum Pemerintahan yang Baik sebagai Dasar Pengujian Keabsahan Keputusan Tata Usaha Negara di Peradilan Tata Usaha Negara”. Yustisia, 1, 2 (2012): 180-93. DOI: 10.20961/yustisia.v1i2.10644.

Suhendar, Endang. "Editorial: Menjadikan Tanah sebagai Komoditas". Jurnal Analisis Sosial, 3 (1996): 3-10.

Surono, Agus. "Perlindungan Hak Korban Pengadaan Tanah untuk Pembangunan Jalan Tol di Kabupaten Kendal.” Jurnal Penelitian Hukum De Jure, 17, 4 (2017): 391-409. DOI: 10.30641 / dejure.2017. V17.391-409. 
Tjondrongeoro, Soediono M.P. “Tanah: Aset Utama Pembangunan. Jurnal Analisis Sosial, 3 (1996): 23-32.

Triningsih, Anna dan Zaka Firma Aditya. "Pembaharuan Penguasaan Hak atas Tanah dalam Perspektif Konstitusi." Jurnal Rechts Vinding: Media Pembinaan Hukum Nasional 8, 3 (2019): 329-49. DOI: 10.33331 / rechtsvinding.v8i3.355.

Tuasikal, Askam. "Pengaruh Pengawasan, Pemahaman Sistem Akuntansi Keuangan dan Pengelolaan Keuangan terhadap Kinerja Unit Satuan Kerja Pemerintah Daerah (Studi pada Kabupaten dan Kota di Provinsi Maluku).” Jurnal Keuangan dan Perbankan, 10, 1 (2017): 1-27.

Zahra, Fatimah Al. "Gagasan Pengaturan Bank Tanah untuk Mewujudkan Pengelolaan Aset Tanah Negara yang Berkeadilan.” Jurnal Ilmiah Administrasi Publik, 3, 2 (2017): 92-101. DOI: 10.21776/ ub.jiap.2017.003.02.2.

Zahra, Fatimah Al. "Konstruksi Hukum Pengaturan Bank Tanah untuk Mewujudkan Pengelolaan Aset Tanah Negara Berkeadilan.” Arena Hukum, 10, 3 (2018): 357-84. DOI: 10.21776/ ub.arenahukum.2017.01003.2. 